\title{
STUDY OF THERAPEUTIC RESPONSE TO SECOND LINE ART REGIMEN IN TERTIARY CARE TEACHING HOSPITAL OF SOUTH INDIA
}

\author{
Padmalatha Pentakota ${ }^{1}$, V. C. Srinivas Reddy², Jyotirmayi Boddu ${ }^{3}$
}

${ }^{1}$ Assistant Professor, Department of Medicine, Andhra Medical College, Visakhapatnam.

${ }^{2}$ Assistant Professor, Department of Medicine, Andhra Medical College, Visakhapatnam.

${ }^{3}$ Assistant Professor, Department of Medicine, Andhra Medical College, Visakhapatnam.

\section{ABSTRACT}

\section{BACKGROUND}

The widespread use of HAART therapy resulted in marked decline in the incidence of most AIDS defining conditions and mortality, both in the developed and developing world. As the scope of ART in developing countries continues, the number of patients failing in first line therapy and switching to second line therapy will inevitably increase. The aim of the study is to assess the therapeutic response by CD4 count and plasma viral load in HIV patients who received $2^{\text {nd }}$ line regimen consisting of tenofovir, lamivudine, Ritonavir and atazanavir.

\section{METHODS}

This was a retrospective observational study. The data was collected retrospectively from the case sheets of the 50 patients of ART Centre of King George Hospital, Visakhapatnam, a tertiary care teaching hospital in South India. Patients in the age group of 18-70 years who were started on $2^{\text {nd }}$ line ART therapy after failure of $1^{\text {st }}$ line therapy as per NACO guidelines were included. The data analysis was carried out using Graph pad prism version 5.0. P value $<0.01$ considered as statistically significant.

\section{RESULTS}

It was observed that mean levels of CD4 after six months of therapy were elevated compared to the initial mean values. The observed difference was statistically significant $(p<0.0001)$. Mean levels of viral load after six months of therapy were decreased compared to the initial mean values. The observed difference was not statistically significant $(\mathrm{p}=0.17)$ (Table 10).

\section{CONCLUSION}

Patients who were initiated on second line therapy after the failure of first line regimen had high rates of immunologic and virologic success and low rates of mortality. This is evident by the increase in CD4 count and decrease in viral load in our study.

\section{KEYWORDS}

HAART, CD4, AIDS, HIV

HOW TO CITE THIS ARTICLE: Pentakota P, Reddy VCS, Boddu J. Study of therapeutic response to second line ART regimen in tertiary care teaching hospital of South India. J. Evolution Med. Dent. Sci. 2016;5(34):1929-1933, DOI: 10.14260/jemds/2016/456

\section{INTRODUCTION}

Highly Active Antiretroviral Therapy (HAART) is the cornerstone of management of patients with HIV infection. The widespread use of antiretroviral therapy resulted in marked decline in the incidence of most AIDS defining conditions and mortality, both in the developed and developing world.[1] Results of three large clinical end point studies demonstrated that combination therapy significantly delayed progression of HIV disease and improved survival.[2]

As the scope of ART in developing countries continues, the number of patients switching to second line therapy will inevitably increase. Divisions about the use of second line regimen in these areas will depend in part on the success of these regimens, but to date there has been little evidence to assess the effectives of these regimens in patients failing in first line therapies.

Financial or Other, Competing Interest: None.

Submission 09-03-2016, Peer Review 04-04-2016,

Acceptance 11-04-2016, Published 28-04-2016.

Corresponding Author:

Dr. Padmalatha Pentakota

Flat No. 201, Coastal Square Apartments,

Official Colony, $1^{\text {st }}$ Lane, Maharanipeta,

Visakhapatnam-530001, Andhra Pradesh.

E-mail: padmalathamdgen@gmail.com

DOI: $10.14260 /$ jemds $/ 2016 / 456$
$\mathrm{ATV} / \mathrm{r}$ ) aims to achieve viral suppression for as long as possible, so that survival can be prolonged. This regimen includes- TDF + 3TC (Fixed dose combination of Tenofovir $300 \mathrm{mg}+$ Lamivudine $300 \mathrm{mg}$ once daily in tablet form) and ATV/r (Tab. Atazanavir 300 mg, Tab. Ritonavir 100 mg- Each tab to be taken once daily simultaneously).[3]

Measuring Plasma Viral Load (PVL) and CD4 counts are crucial for initiating and modifying ART therapy. While PVL indicates the magnitude of viral replication; CD4 counts indicate the extent of immune system damage. PVL indicates the amount of viral RNA/DNA particles per mL of blood and is best predictor of long term prognosis, whereas CD4 count is best predictor of short term prognosis like opportunistic infections.[4] In fact, the very goal of therapy has been redefined as the achievement of maximal durable suppression of virus replication on a long term basis. ${ }^{[5,6]}$

Number of drugs available for therapy is limited and moreover cross-resistance between specific drugs has been documented. In this present situation, any change in ART regimes increases future therapeutic constraints like virologic failure, adverse drug side effects and impact on adherence and mortality.

So this study was conducted to assess therapeutic efficacy of second line ART drugs and their side effects at ART centre of King George Hospital, Visakhapatnam, a Tertiary Care Teaching Hospital of South India. 


\section{AIM}

\section{Primary Outcome}

To study therapeutic response by CD4 count and plasma viral load in HIV patients who received $2^{\text {nd }}$ line regimen consisting of tenofovir, lamivudine, ritonavir and atazanavir.

\section{Secondary Outcome}

To study the effect of $2^{\text {nd }}$ line regimen on Renal Function Tests, Liver Function Tests, Lipid Profile and Haemogram.

\section{MATERIAL AND METHODS}

This was a retrospective observational study. The data was collected retrospectively from the case sheets of the 50 patients of ART Centre of King George Hospital, Visakhapatnam, a Tertiary Care Teaching Hospital in South India. The permission of the institutional head and approval of Institutional Ethics Committee was obtained. Patient confidentiality was maintained. Patients in the age group of 18-70 years who were started on $2^{\text {nd }}$ line ART therapy after failure of $1^{\text {st }}$ line therapy as per NACO guidelines.[3] were included and patients who were pregnant, lactating, having pre-existing abnormal liver, renal function tests, lipid profiles were excluded.

\section{The following Data was collected Demographic Data \\ - Age. \\ - Gender. \\ - Family History. \\ - Marital Status. \\ - $\quad$ First Line ART initiation Date. \\ - Second line ART initiation Date. \\ - Opportunistic infections. \\ - Adherence to therapy.}

Laboratory Data: At the time of initiation of 2nd line therapy consisting of tenofovir, lamivudine, ritonavir, atazanavir and at the end of 6 months of treatment,

- $\quad \mathrm{CD}_{4}$ Count.

- Plasma Viral Load.

- Complete Blood Picture.

- Liver Function Tests.

- Renal Function tests.

- Lipid Profiles.

The data analysis was carried out using Graph pad prism version 5.0. $\mathrm{P}$ value $<0.01$ considered as statistically significant.

\section{RESULTS}

Of all patients, maximum patients belonged to the age group of 31-40 years (50\%) (Table 1). The mean age of patients was 35 years; 33 were men and 17 were women (Table 2); 90\% patients were married, $6 \%$ were unmarried and $4 \%$ were widowed (Table 3). Of 50 patients, 25 patients were seroconcordant (Table 4).

In our study, there were no opportunistic infections in $72 \%$ of patients, $24 \%$ were effected with TB and $4 \%$ were effected with other infections (Table 5). Of all patients enrolled in study, $34 \%$ patients were on $1^{\text {st }}$ line regimen for 5-6 years following $28 \%$ for $1-2$ years, $12 \%$ for 7 years and above and $26 \%$ for 3-4 years (Table 6). Different types of first line treatment regimens were available for HIV treatment, among which $68 \%$ received ZLN, $20 \%$ received SLN, $8 \%$ received ZLE, $2 \%$ received TLN and $2 \%$ received TLE $1{ }^{\text {st }}$ line regimens (Table 7). Compliance with therapy was good in $52 \%$ patients followed by $38 \%$ with excellent adherence, $10 \%$ with poor adherence (Table 8). There were $15 \%$ dropouts and $1.67 \%$ deaths (Table 9). It was observed that mean levels of CD4 after six months of therapy were elevated compared to the initial mean values. The observed difference was statistically significant $(p<0.0001)$. Mean levels of viral load after six months of therapy were decreased compared to the initial mean values. The observed difference was not statistically significant $(\mathrm{p}=0.17)$ (Table 10$)$.

On comparing the haemograms (Table 11), after six months the mean haemoglobin levels after six months of therapy increased from $10.32 \mathrm{gm} / \mathrm{dL}$ to $10.52 \mathrm{gm} / \mathrm{dL}$. Mean total count levels after six months of therapy were elevated from 6277 cells/cumm to 6594 cells/cumm. Mean neutrophil levels decreased from mean of $62 \%$ to $60 \%$. Mean ESR levels after six months of therapy were decreased from $46 \mathrm{~mm} / \mathrm{hr}$ to $42 \mathrm{~mm} / \mathrm{hr}$. The observed differences were not statistically significant. Mean lymphocytes levels after six months of therapy were increased from $31 \%$ to $35 \%$. The observed difference was statistically significant $(\mathrm{p}=0.01)$.

At the end of six months therapy (Table 12), there was increase in mean total and direct bilirubin, alkaline phosphatase and decrease in mean SGOT and SGPT. Similarly, the mean serum creatinine levels after six months of therapy were increased from $0.91 \mathrm{mg} / \mathrm{dL}$ to $1.0 \mathrm{mg} / \mathrm{dL}$ (Table 13). Mean BUN levels after six months of therapy were increased from $26 \mathrm{mg} / \mathrm{dL}$ to $27 \mathrm{mg} / \mathrm{dL}$. The above differences were not statistically significant.

While comparing the changes in lipid profile (Table 14), it was observed that mean levels of serum total cholesterol after six months of therapy were elevated from $147 \mathrm{mg} / \mathrm{dL}$ to $157 \mathrm{mg} / \mathrm{dL}$. Mean levels of HDL (from $39 \mathrm{mg} / \mathrm{dL}$ to 44 $\mathrm{mg} / \mathrm{dL}$ ), LDL (From $74 \mathrm{mg} / \mathrm{dL}$ to $84 \mathrm{mg} / \mathrm{dL}$ ), VLDL after six months of therapy were elevated compared to the initial mean values. Mean RBS levels after six months of therapy were elevated from $98 \mathrm{mg} / \mathrm{dL}$ to $108 \mathrm{mg} / \mathrm{dL}$. The observed differences were not statistically significant.

\begin{tabular}{|c|c|c|}
\hline Age Group & Number of Patients & Percentage \\
\hline $11-20$ & 01 & $2 \%$ \\
\hline $21-30$ & 13 & $26 \%$ \\
\hline $31-40$ & 25 & $50 \%$ \\
\hline $41-50$ & 09 & $18 \%$ \\
\hline $51-60$ & 02 & $4 \%$ \\
\hline $61-70$ & 0 & $0 \%$ \\
\hline Total & $\mathbf{5 0}$ & $\mathbf{1 0 0 \%}$ \\
\hline \multicolumn{2}{|c|}{ Table 1: Age Distribution of Patients } \\
\hline
\end{tabular}

Of all patients, maximum patients belonged to the age group of 31-40 years (50\%).

\begin{tabular}{|c|c|c|}
\hline Gender & Number of Patients & Percentage \\
\hline Females & 17 & $34 \%$ \\
\hline Males & 33 & $66 \%$ \\
\hline Total & $\mathbf{5 0}$ & $\mathbf{1 0 0} \%$ \\
\hline \multicolumn{2}{|c|}{ Table 2: Gender Distribution of Patients } \\
\hline
\end{tabular}


The mean age of patients was 35 years; 33 were men and 17 were women.

\begin{tabular}{|c|c|c|}
\hline Marital Status & Number of Patients & Percentage \\
\hline Married & 45 & $90 \%$ \\
\hline Unmarried & 03 & $6 \%$ \\
\hline Widow & 02 & $4 \%$ \\
\hline Total & $\mathbf{5 0}$ & $\mathbf{1 0 0} \%$ \\
\hline \multicolumn{2}{|c|}{ Table 3: Marital Status of Patients } \\
\hline
\end{tabular}

$90 \%$ patients were married, $6 \%$ were unmarried and $4 \%$ were widowed.

\begin{tabular}{|c|c|c|}
\hline Spouse & Number of Patients & Percentage \\
\hline Positive & 25 & $50 \%$ \\
\hline Negative & 25 & $50 \%$ \\
\hline Total & $\mathbf{5 0}$ & $\mathbf{1 0 0} \%$ \\
\hline \multicolumn{2}{|c|}{ Table 4: Serological Concordance } \\
\hline
\end{tabular}

Of 50 patients, 25 patients were seroconcordant.

\begin{tabular}{|c|c|c|}
\hline Type of Infection & Number of Patients & Percentage \\
\hline Tuberculosis & 12 & $24 \%$ \\
\hline Other & 02 & $04 \%$ \\
\hline Without infection & 36 & $72 \%$ \\
\hline Total & 50 & $100 \%$ \\
\hline
\end{tabular}

There were no opportunistic infections in $72 \%$ of patients, $24 \%$ were effected with TB and $4 \%$ were effected with other infections.

\begin{tabular}{|c|c|c|}
\hline Duration (yrs.) & Number of Patients & Percentage \\
\hline $1-2$ & 14 & $28 \%$ \\
\hline $3-4$ & 13 & $26 \%$ \\
\hline $5-6$ & 17 & $34 \%$ \\
\hline Above 7 & 06 & $12 \%$ \\
\hline Total & $\mathbf{5 0}$ & $\mathbf{1 0 0} \%$ \\
\hline \multicolumn{3}{|c|}{ Table 6 } \\
\hline
\end{tabular}

Of all patients enrolled in study, 34\% patients were on $1^{\text {st }}$ line regimen for $5-6$ years following $28 \%$ for $1-2$ years, $12 \%$ for 7 years and above and $26 \%$ for $3-4$ years.

\begin{tabular}{|c|c|c|}
\hline Regimen & Number of Patients & Percentage \\
\hline ZLN & 34 & $68 \%$ \\
\hline SLN & 10 & $20 \%$ \\
\hline ZLE & 04 & $08 \%$ \\
\hline TLN & 01 & $02 \%$ \\
\hline TLE & 01 & $02 \%$ \\
\hline Total & $\mathbf{5 0}$ & $\mathbf{1 0 0 \%}$ \\
\hline \multicolumn{3}{|c|}{$\begin{array}{c}\text { Table 7: 1st Line Treatment Regimens } \\
\text { used by the Patients }\end{array}$} \\
\hline
\end{tabular}

Different types of first line treatment regimens were available for HIV treatment among which $68 \%$ received ZLN, $20 \%$ received SLN, $8 \%$ received ZLE, $2 \%$ received TLN and $2 \%$ received TLE $1^{\text {st }}$ line regimens.

\begin{tabular}{|c|c|c|}
\hline Adherence & $\begin{array}{c}\text { Number of } \\
\text { Patients }\end{array}$ & Percentage \\
\hline Excellent & 19 & $38 \%$ \\
\hline Good & 26 & $52 \%$ \\
\hline Poor & 05 & $10 \%$ \\
\hline Total & $\mathbf{5 0}$ & $\mathbf{1 0 0 \%}$ \\
\hline \multicolumn{2}{|c|}{ Table 8: Adherence to Therapy } \\
\hline
\end{tabular}

Compliance with therapy was good in $52 \%$ patients followed by $38 \%$ with excellent adherence, $10 \%$ with poor adherence.

\begin{tabular}{|c|c|c|}
\hline & Number of Patients & Percentage \\
\hline Dropouts & 9 & $15 \%$ \\
\hline Deaths & 1 & $1.67 \%$ \\
\hline \multicolumn{2}{|c|}{ Table 9: Assessment of Dropouts and Deaths } \\
\hline
\end{tabular}

There were $15 \%$ dropouts and $1.67 \%$ deaths.

\begin{tabular}{|c|c|c|c|}
\hline \multirow[b]{2}{*}{ Parameters } & \multicolumn{2}{|c|}{ Mean \pm SD } & \multirow{2}{*}{$\begin{array}{c}P ' \\
\text { Value }\end{array}$} \\
\hline & Baseline & After & \\
\hline $\begin{array}{c}\text { CD4 Count } \\
\text { (cells } / \mathrm{mm}^{3} \text { ) }\end{array}$ & $104.18 \pm 84.70$ & $225.93 \pm 148.19$ & $<0.0001$ \\
\hline $\begin{array}{c}\text { Viral Load } \\
\text { (copies/mL) }\end{array}$ & $\begin{array}{c}254085.96 \pm \\
313690.14\end{array}$ & $\begin{array}{c}156778.79 \pm \\
397876.57\end{array}$ & 0.17 \\
\hline
\end{tabular}

It was observed that mean levels of CD4 after six months of therapy were elevated compared to the initial mean values. The observed difference was statistically significant $(\mathrm{p}<0.0001)$.

Mean levels of viral load after six months of therapy were decreased compared to the initial mean values. The observed difference was not statistically significant $(p=0.17)$ (Table 10).

\begin{tabular}{|c|c|c|c|}
\hline \multirow{2}{*}{ Parameters } & \multicolumn{2}{|c|}{ Mean \pm SD } & 'P' \\
\cline { 2 - 3 } Value
\end{tabular}

Table 11: Assessment of Complete Blood Count

On comparing the haemograms (Table 11) after six months, the mean haemoglobin levels after six months of therapy increased from $10.32 \mathrm{gm} / \mathrm{dL}$ to $10.52 \mathrm{gm} / \mathrm{dL}$. Mean total count levels after six months of therapy were elevated from 6277 cells/cumm to 6594 cells/cumm. Mean neutrophil levels decreased from mean of $62 \%$ to $60 \%$. Mean ESR levels after six months of therapy were decreased from $46 \mathrm{~mm} / \mathrm{hr}$ to $42 \mathrm{~mm} / \mathrm{hr}$.

The observed differences were not statistically significant. Mean lymphocytes levels after six months of 
therapy were increased from $31 \%$ to $35 \%$. The observed difference was statistically significant $(\mathrm{p}=0.01)$.

\begin{tabular}{|c|c|c|c|}
\hline \multirow{2}{*}{ Parameters } & \multicolumn{2}{|c|}{ Mean \pm SD } & \multirow{2}{*}{$\begin{array}{c}\text { 'P' } \\
\text { value }\end{array}$} \\
\cline { 2 - 3 } & Baseline & After & 0.23 \\
\hline $\begin{array}{c}\text { Bilirubin } \\
\text { (T) (mg/dL) }\end{array}$ & $1.02 \pm 0.96$ & $1.29 \pm 1.20$ & 0.42 \\
\hline $\begin{array}{c}\text { Bilirubin (D) } \\
\text { (mg/dL) }\end{array}$ & $0.36 \pm 0.39$ & $0.43 \pm 0.43$ & 0.33 \\
\hline $\begin{array}{c}\text { Bilirubin } \\
\text { I) (mg/dL) }\end{array}$ & $0.66 \pm 0.66$ & $0.83 \pm 1.0$ & 0.52 \\
\hline SGOT (IU/L) & $42.17 \pm 29.97$ & $38.92 \pm 20.77$ & 0.30 \\
\hline SGPT (IU/L) & $39.31 \pm 23.93$ & $34.64 \pm 21.21$ & 0.94 \\
\hline ALP (IU/L) & $131.2 \pm 74.53$ & $132.12 \pm 50.80$ & \\
\hline \multicolumn{3}{|c|}{ Table 12: Assessment of Liver Function Tests } \\
\hline \multicolumn{4}{|c|}{}
\end{tabular}

At the end of six months therapy (Table 12), there was increase in mean total and direct bilirubin, alkaline phosphatase and decrease in mean SGOT and SGPT.

\begin{tabular}{|c|c|c|c|}
\hline Parameters & $\begin{array}{c}\text { Baseline } \\
\text { Mean } \pm \text { SD }\end{array}$ & After Mean \pm SD & $\begin{array}{c}\text { 'P' } \\
\text { Value }\end{array}$ \\
\hline $\begin{array}{c}\text { Sr. Creatinine } \\
(\mathrm{mg} / \mathrm{dL})\end{array}$ & $0.91 \pm 0.33$ & $1.0 \pm 0.31$ & 0.21 \\
\hline BUN (mg/dL) & $26.96 \pm 13.28$ & $27.22 \pm 8.57$ & 0.90 \\
\hline \multicolumn{3}{|c|}{ Table 13: Assessment of Renal Function Tests } \\
\hline
\end{tabular}

Similarly, the mean serum creatinine levels after six months of therapy were increased from $0.91 \mathrm{mg} / \mathrm{dL}$ to 1.0 $\mathrm{mg} / \mathrm{dL}$ (Table 13). Mean BUN levels after six months of therapy were increased from $26 \mathrm{mg} / \mathrm{dL}$ to $27 \mathrm{mg} / \mathrm{dL}$. The above differences were not statistically significant.

\begin{tabular}{|c|c|c|c|}
\hline \multirow{2}{*}{ Parameters } & \multicolumn{2}{|c|}{ Mean \pm SD } & 'P' \\
\cline { 2 - 3 } Value
\end{tabular}

While comparing the changes in lipid profile (Table 14), it was observed that mean levels of serum total cholesterol after six months of therapy were elevated from $147 \mathrm{mg} / \mathrm{dL}$ to $157 \mathrm{mg} / \mathrm{dL}$. Mean levels of HDL (From $39 \mathrm{mg} / \mathrm{dL}$ to 44 $\mathrm{mg} / \mathrm{dL}$ ), LDL (From $74 \mathrm{mg} / \mathrm{dL}$ to $84 \mathrm{mg} / \mathrm{dL}$ ), VLDL after six months of therapy were elevated compared to the initial mean values.

Mean RBS levels after six months of therapy were elevated from $98 \mathrm{mg} / \mathrm{dL}$ to $108 \mathrm{mg} / \mathrm{dL}$. The observed differences were not statistically significant.

\section{DISCUSSION}

As the scope of ART in developing countries continues, the number of patients switching to second line therapy will inevitably increase. Divisions about the use of second line regimen in these areas will depend in part on the success of these regimens, but to date there has been a little evidence to assess the effectives of these regimens in patients failing in first line therapies.

Our study showed that the most common age group was 21-40 years with $94 \%$ of our patients belonging to the reproductive age group (20-50 years). The mean age of patients was 35 years, which is comparable to studies of Pujades-Rodríguez M et al (35 years).[7] Men constituted 66\% of our study subjects. This was comparable to national data that shows $61 \%$ of the total HIV infected patients are men.[8] Our study had $50 \%$ seroconcordance among couples, which is less than $66 \%$ noted by Dishank Patel et al[9], 72\% of our study patients did not have any opportunistic infections. The most common opportunistic infection was tuberculosis in 12 (24\%), which was more than the findings of Dishank Patel et al $(14 \%) \cdot{ }^{[9]}$

Findings of this analysis indicate that majority of patients with HIV drug resistance to first line therapy achieved viral suppression after switching to second line therapy. We have demonstrated substantial mean increase in CD4 count in patients on second line therapy, an average of 120 cells/UL over the observed period. This is again similar to the MSF cohort, where patients had a median CD4 count increase at 12 months of 135 cells/UL by Puades Rodriguey M et al.[7] Although not universally accepted, an increase of 100 cells/UL over the first year on therapy can be seen as a marker of treatment success on first line therapy, when most patients are initiated at CD4 counts below 200. In comparison the average gain of 124 cells in 6 months on second line seen in our study represents substantial immune recovery.

The reported rates of mortality among patients on second line ART substantially ranging from $3 \%$ to $16 \%$ (Castelnuovo B et al).[10] In our study, 1.67\% patients died on the follow-up.

As more patients are initiated on second line regimens, being able to identify which patients fail these regimens and why will be critical to the long-term durability of these regimens. The data on adherence to second line therapy, the most predictor of achieving viral suppression. Overall adherence was high as treatment success rates were high, but overtime adherence rates may decline leading to more failures.

The effect of second line regimen on different laboratory parameters assessed was not statistically significant for this shorter duration of study, but on long-term follow the results may depict clearer picture.

Our study had few limitations. First, this was a small group of patients, so limited generalization of our findings. Also, ours is a retrospective analysis utilizing routinely available data, thus there might have been some unmeasured factors that influenced the outcomes.

\section{CONCLUSION}

In conclusion, we found that patients who were initiated on second line therapy after the failure of first line regimen had high rates of immunologic and virologic success and low rates 
of mortality. This part is evident by the increase in CD4 count and decrease in viral load in our study. Further research is needed to determine if these findings can be extended to different settings and longer follow-up will be needed to determine if these early outcomes can be sustained over the long term treatment.

\section{REFERENCES}

1. Palella FJ, Delaney KM, Moorman AC, et al. Declining morbidity and mortality among patients with advanced human immunodeficiency virus infection. HIV out patient study investigators. NEJM 1998;338(13):853-60.

2. Feinberg MB, Carpenter C, Fauci AS, et al. Report of the NIH panel to define principles of therapy of HIV infection and guidelines for the use of antiretroviral agents in HIV infected adults and adolescents. Ann Intern Med 1998;128:1057-110.

3. National guidelines on second-line and alternative firstline ART for adults and adolescents. The National AIDS Control organisation 2013;1-105.

4. Saag MS, Holodniy M, Kuritzkes DR, et al. HIV viral load markers in clinical practice. Nat Med 1996;2(6):625-9.
5. Carpenter CCJ, Fischl MA, Hammer SM, et al. Antiretroviral therapy for HIV infection in 1998. Recommendations of an international panel. JAMA 1998;280(1):78-86.

6. Gazzard BG, Moyle GJ, Weber J, et al. British HIV association guidelines for antiretroviral treatment of HIV seropositive individuals. Lancet 1997;349(9058):108692.

7. Pujades-Rodríguez M, O’Brien D, Humblet P, et al. Secondline antiretroviral therapy in resource-limited settings: the experience of médecins sans frontières. AIDS 2008;22(11):1305-12.

8. NACO annual report 2010-11.

9. Dishank Patel, Mira Desai, Shah AN, et al. Early outcome of second line antiretroviral therapy in treatmentexperienced human immunodeficiency virus positive patients. Perspect Clin Res 2013;4(4):215-20.

10. Castelnuovo B, John L, Lutwama F, et al. Three-year outcome data of second-line antiretroviral therapy in ugandan adults: good virological response but high rate of toxicity. J Int Assoc Physicians AIDS Care (Chic) 2009;8(1):52-9. 